\title{
Opportunities for Research and Publication in Accounting: A Preliminary Study on Academic Journals Published in English and Available at the CAPES's Basis
}

\author{
José Alonso Borba * \\ Federal University of Santa Catarina \\ Fernando Dal-Ri Murcia ** \\ Univali-Florianópolis SC
}

\begin{abstract}
This paper uses an exploratory approach to learn some of the characteristics of accounting journals published in English and available at the CAPES Periodicals Portal. This study's sample is composed of the journals that have the words "accounting", "auditing", "cost" and "accountability" in their title. A content analysis was carried out of the journals' editorial boards, guides for authors and aim/focus in order to classify the sample chosen. This classification relied on the following aspects: country of origin, electronic distributor, focus, frequency, blind review, indexing with the Institute for Scientific Information (ISI), indexing with Scopus and impact factor according to Journal Citation Reports (JCR). This paper' main contribution is to identify and classify academic publications on accounting in English available at the CAPES portal, to encourage Brazilian researchers to broaden their horizons by informing them of the range of publications available.
\end{abstract}

Keywords: accounting research, Capes portal, accounting journals, journal evaluation, international dissemination.

Received in 08/09/2005; revised in 12/12/2005; accept in 20/02/2006.

Corresponding authors:

José Alonso Borba

Doutor em Controladoria e Contabilidade

Universidade Federal de Santa Catarina

Endereço: Campus Universitário, Trindade, 88040-500 -

Florianopolis, $\mathrm{SC}$ - Brasil

Email: j.alonso@ufsc.br

Telefone: (48) 37216608
Fernando Dal-Ri Murcia

Doutor em Controladoria e Contabilidade Universidade de São Paulo

Endereço: Av. Prof. Luciano Gualberto, 908 - Prédo III, Cidade Universitária, 05508900 - Sao Paulo, SP - Brasil

Email: fernandomurcia@hotmail.com

Telefone: (11) 30915820 


\section{INTRODUCTION}

Publication of academic research is one of the most important ways to disseminate scientific knowledge to the world (Tahai and Rigsby, 1997). The normal routes are submission to a journal followed by presentation at congresses and seminars (working papers). The criticisms received are reflected and the author then resubmits the article for definitive publication, in reviews, magazines or books (chapters). Normally this definitive publication involves more developed research resulting from master's dissertations, doctoral theses or works from research groups.

According to Oliveira (2002), the publication of articles in periodicals is an important part of the flow of information from scientific research. Similarly, Frezatti and Borba (2000) stress that publishing in specialized periodicals is an important factor in the career advancement of researchers, because it is the way scientists share their findings with colleagues. As the saying goes publish.

In Brazil, specifically in the area of accountancy, scientific knowledge is disseminated slowly, with little publication in periodicals considered to be "high level". According to Mendonça Neto et al. (2004), Brazilian authors in the accounting area have low productivity in relation to their international peers, but also inferior to their compatriots in other areas, such as finance and administration. The results of this study show that academic production in accounting represents only $2.95 \%$ of the articles published in A-level journals as ranked by CAPES/Qualis from 1990 to 2003.

Regarding the theoretical reference of Brazilian publications, Martins and Silva (2005) point out the very low rate of consulting both national and international periodicals. It appears symptomatic to cite many books in Brazilian academic works in the field of accounting. In contrast, in works abroad the references are predominantly articles - considered state of the art - resulting from studies and research investigating similar or related problems. The objective is to advance knowledge, based on the latest discoveries reported by the academic community.

The advent of the Internet and the availability online of a great part of academic output has reduced the inequalities in accessing information among universities and researchers. In this sense, Brazilian researchers now have access to information similar to their peers at institutions such as Harvard and Oxford.

The present work aims to open a horizon for publication and research in the rich data mine available to most Brazilian universities, by examining some of the most relevant characteristics of journals, reviews and other periodicals in the accounting field in English, available at the periodicals portal of CAPES.

The rest of this article is organized as follows. First some of the main Brazilian and international studies are presented involving accounting teaching and research. Then some considerations are made on the CAPES portal, followed by an explanation of the methodology used. Finally, the results are shown, followed by some conclusions and recommendations.

\section{THEORETICAL GROUNDS}

There have been a number of studies in Brazil on themes related to education, teaching and research in accounting. Marion (1992) analyzed various aspects of accounting teaching in the United States. Germano (1988) developed a study on the doctoral theses in accounting at the University of São Paulo through 1988. Riccio, Carastan and Sakata (1999) analyzed the characteristics of Brazilian academic output - master's dissertations and doctoral theses - 
from 1962 to 1999. Riccio and Sakata (2004) conducted a survey to assess the curricula of accounting science programs at universities in Brazil and Portugal.

Mendonça Neto et al. (2004) examined accounting articles published in Brazilian reviews ranked at the A level by CAPES in the period 1990-2003. Theóphilo and Iudícibus (2005) investigated the scientific production in Brazil from an epistemological standpoint. Martins and Silva (2005) conducted a bibliometric study that analyzed the theoretical platform utilized by authors of works published in the proceedings of the USP Congresses on Control and Accounting in 2003 and 2004. Leite Filho and Martins (2005) analyzed the student-faculty advisor relationship in preparation of theses and dissertations in accounting. Oliveira (2002) looked at the characteristics of Brazilian accounting periodicals according to criteria such as editorial board, access/distribution, normalization and articles published.

Internationally, Beattie and Goodacre (2003) carried out a study in the United Kingdom on the publishing standards in the academic community in the areas of accountancy and finance, finding that only $17 \%$ of academics published in the 60 leading periodicals. Chang, Cheng and Cheng (2005) utilized a sample of 23 academic periodicals to establish a ranking for 119 accounting study programs in countries in Asia and reported that the productivity of professors at the leading Asian universities is comparable to those at the main American institutions. Brow (2003) established a ranking for doctoral programs in accounting using as a basis the number of downloads from the academic research site of the Social Science Research Network (SSRN) (www.ssrn.com).

Academic works that analyze scientific periodicals on accounting published in English have been conducted by various researchers. Chart 1 presents a brief summary of some of these.

Chart 1. Studies of Academic Periodicals on Accounting.

\begin{tabular}{l|l}
\hline \multicolumn{1}{c|}{ Author(s) / Periodical } & \multicolumn{1}{c}{ Description } \\
\hline $\begin{array}{l}\text { Howard and Nikolai (1983) } \\
\text { Accounting Review }\end{array}$ & $\begin{array}{l}\text { Established a ranking for accounting periodicals } \\
\text { published by American universities. }\end{array}$ \\
\hline $\begin{array}{l}\text { Hull and Wright (1990) } \\
\text { Accounting Horizons }\end{array}$ & $\begin{array}{l}\text { Conducted a survey based on the study of } \\
\text { Howard and Nikolai (1983) and used the opinions } \\
\text { of accounting professors at American universities } \\
\text { as a criterion for ranking the periodicals. }\end{array}$ \\
\hline $\begin{array}{l}\text { Smith (1994) } \\
\text { Accounting Educators Journal }\end{array}$ & $\begin{array}{l}\text { Examined the contribution of 93 academic } \\
\text { periodicals to accounting theory. }\end{array}$ \\
\hline $\begin{array}{l}\text { Lukka and Kasanen (1996) } \\
\text { Society }\end{array}$ & $\begin{array}{l}\text { Analyzed the articles published in } 6 \text { of the } \\
\text { leading accounting journals to verify the } \\
\text { amplitude of these publications. }\end{array}$ \\
\hline $\begin{array}{l}\text { Zeff (1996) } \\
\text { Accounting Horizons }\end{array}$ & $\begin{array}{l}\text { Investigated the emergence of new publications } \\
\text { and identified a total of 77 accounting science } \\
\text { periodicals in English. }\end{array}$ \\
\hline $\begin{array}{l}\text { Tahai and Rigbsy (1998) } \\
\text { Information Processing \& } \\
\text { Management }\end{array}$ & $\begin{array}{l}\text { Conducted a survey of } 48 \text { academic periodicals } \\
\text { on accounting to investigate the durability of the } \\
\text { research in accounting by analysis of citations. }\end{array}$ \\
\hline
\end{tabular}




\begin{tabular}{l|l}
\hline $\begin{array}{l}\text { Prather-Kinseye and Rueschoff } \\
\text { (1999) }\end{array}$ & $\begin{array}{l}\text { Analyzed the relationship between international } \\
\text { research in accounting and the respective authors } \\
\text { in } 31 \text { academic periodicals between } 1980 \text { and } \\
1996 .\end{array}$ \\
\hline $\begin{array}{l}\text { Frezatti and Borba (2000) } \\
\text { Caderno de Estudos - USP }\end{array}$ & $\begin{array}{l}\text { Utilized criteria such as review area, frequency of } \\
\text { publication, dimension of quantitative methods } \\
\text { applied and main emphases to outline the profile } \\
\text { of a sample of } 118 \text { accounting reviews and } \\
\text { magazines in English. }\end{array}$ \\
\hline $\begin{array}{l}\text { Lowe and Locke (2005) } \\
\text { Accounting, Organization and }\end{array}$ & $\begin{array}{l}\text { Classified accounting periodicals through the } \\
\text { opinions of the academic community in the } \\
\text { United Kingdom. }\end{array}$ \\
\hline
\end{tabular}

Source: The authors.

\section{THE CAPES PERIODICALS PORTAL}

CAPES (Coordination for Improvement of University Level Personnel) created and maintains a periodicals portal to offer scientific information to the Brazilian academic community. Access to the site is unlimited and free to all professors, researchers, employees and students (undergraduate and postgraduate) of the 152 participating institutions.

These institutions were chosen considering CAPES' mission to help raise the quality of college education by fostering postgraduate study. Institutions in the following categories have access to the CAPES Periodicals Portal (2005, www.periodicos.capes.gov.br):

Federal colleges and universities;

A Research institutions with postgraduate programs evaluated by CAPES;

(1) Public state and municipal institutions with postgraduate programs evaluated by Capes;

Private colleges and universities with at least one doctoral program rated 5 or above by CAPES;

Other institutions that join the portal in the "paying" category, with access restricted to the collections contracted.

The portal offers access to 10,000 academic periodicals, besides summaries of works in all areas of knowledge from around the world. Among the main electronic providers that reproduce periodicals in the area of applied social sciences available through the CAPES portal are Blackwell, Science Direct, Infotrack, Proquest, Gale, Wilson, Emerald, and Kluwer. The portal is a rich source of academic information and has contributed greatly to the growing dissemination of scientific output in Brazil. According to Soares (2004), Brazilian researchers, who only ten years ago had no access to updated bibliographical data in their areas, now have access to information comparable to their colleagues at the leading universities in the world.

\section{METHODOLOGY}

This study employs an exploratory approach, seeking to learn the characteristics of the accounting periodicals published in English available at the CAPES Periodicals Portal. The method is divided in two parts: selection of the periodicals and analysis of their editorial boards. 


\subsection{Sample Selection}

To choose the accounting reviews in English available at the CAPES Periodicals Portal, we searched titles at the portals main page. Since it offers access to over 10,000 periodicals, we limited the search by using four key words: accounting, accountability, auditing and cost. For example, the periodical Management Accounting Research was selected because it contains the word accounting in its title. On the other hand, Journal of Finance was not chosen, which does not mean to say this publication - one of the main ones in the area of finance - never covers accounting themes. In this sense, this is a restriction of the methodology, because subjects related to accounting are discussed in many other journals. For example, there are approximately 75 business journals, 70 in the area of finance and 311 on management available at the site.

Subsequently, we eliminated duplicate or triplicate titles - those that were chosen in more than one search. This was the case of Accounting, Auditing and Accountability Journal, which was selected in the first, second and third searches because its title contains three of the four key words.

Finally, we eliminated the periodicals that had been chosen in the searches but that did not cover themes related to accounting. Following the same method, we eliminated others, leaving a final total of 49 periodicals for further analysis. The sample was selected in October 2005. It should be pointed out that there is a turnover of titles at the site, with additions and deletions. Thus, other studies seeking to replicate this method may not find exactly the same sample.

\subsection{Analysis of the Editorial Boards, Guides for Authors and Aim/Focus}

Having defined the sample, the next step was to analyze the 49 periodicals. Through the sites of the electronic distributors (Blackwell, Science Direct, Infotrack, Proquest, Gale, Wilson, Emerald, and Kluwer) it is possible to find the basic details on each periodical. Some of these providers offer a direct link to the home page of the periodicals. Others only provide a link to the institution (universities, institutes, associations, etc.) that publish the titles.

To learn the characteristics of the sample chosen, we decided to analyze the content of the editorial board, guide for authors and aim scope of each periodical. According to Bardin (1977), content analysis permits making inferences from indicators, whether quantitative or otherwise. Thus, this set of techniques enables making comparisons among the elements analyzed. (Franco, 2003).

Eight criteria were defined for analysis:

Country of origin;

Electronic provider;

Indexing with the Institute for Scientific Information (ISI) and the Scopus database (both for 2005);

Level of impact according to Journal Citation Reports (JCR), in 2004;

(17) Aim/focus;

An Frequency of publication;

(1) Blind review;

(1) Payment of a fee to submit articles.

\section{ANALYSIS OF THE RESULTS}

The presentation of the results of this study is divided into four parts. The first explains the analysis of the country of origin; the second looks at the electronic distributors; 
the third presents the periodicals that are indexed; and finally, there is a cluster classification of the sample analyzed.

\subsection{Country of Origin}

The CAPES site contains links mainly to accounting publications in English from the United States. Of the 49 periodicals selected, 33 were of American origin. England placed second, with eight periodicals, followed by Australia/New Zealand with four, Canada with three and Spain with one. Graph 1 depicts the periodicals' countries of origin (in \%).

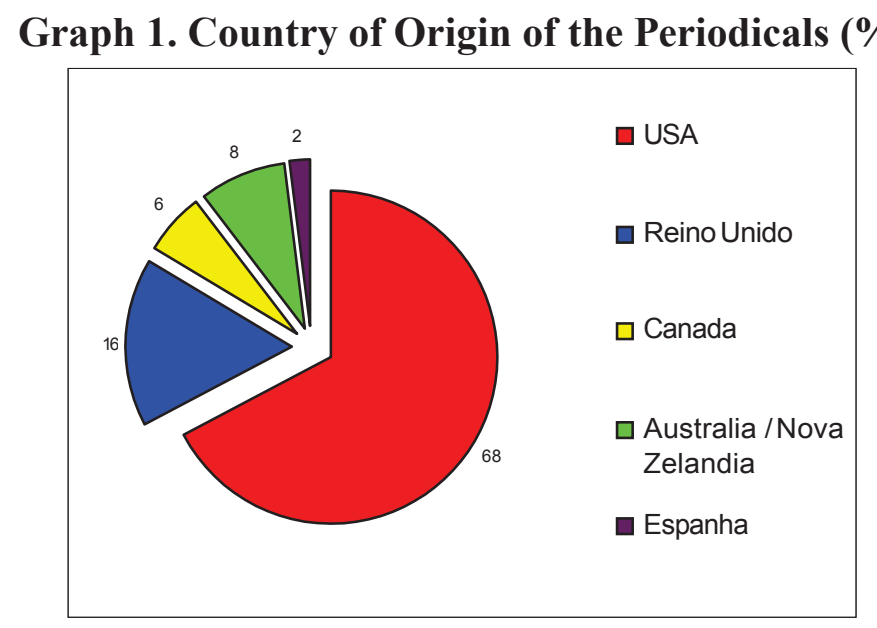

Source: The authors.

The American entity with the largest number of periodicals was the American Accounting Association (http://aaahq.org/index.cfm.), with seven, among them The Accounting Review, Issues in Accounting Education and Accounting Horizons. This association has another four periodicals with accounting content that were not available at the CAPES portal: Accounting and the Public Interest, Journal of American Taxation Association, Journal of Emerging Technologies in Accounting and Journal of Legal Tax Research.

\subsection{Electronic Distributor}

Unlike in the past, when publishers of paper magazines placed their electronic versions for subscription at their own sites, nowadays distribution of the main academic journals and reviews is normally done by an electronic distributor (provider). For example, ProQuest makes available 25 of the 49 titles chosen for this study. Science Direct was second, with 12 publications, followed by Blackwell with 6 . Graph 2 shows the participation of all the distributors of the chosen titles. 


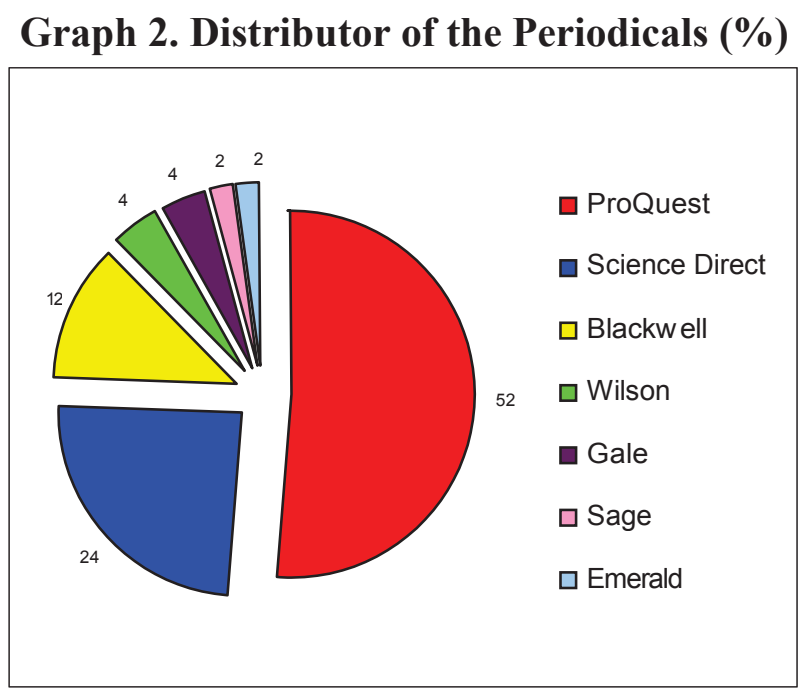

Source: The authors.

\subsection{Indexing of the Accounting Periodicals}

This study also sought to verify the relevance of the accounting periodicals available at the CAPES portal. To do this, three criteria were used: indexing in the Scopus database (www.info.scopus.com), indexing with the Institute for Scientific Information (ISI: www.isinet.com), and the level of impact according to Journal Citation Reports (JCR).

Scopus is a multidisciplinary database that indexes over 14,000 scientific periodicals from more than 4,000 publishers that maintain a peer-review editorial policy. It indexes the periodicals of the following publishers available at the portal: ACM, ACS, AIP/APS, APA, Blackwell, Cambridge, Emerald, HighWire, IEEE/IEE, Nature, OECD, Oxford, Sage, Elsevier/Science Direct and Springer. However, it does not evidence the level of impact of the various publications.

This database also offers the Scopus Citation Tracker service, whereby it is possible to select specific authors, periods and articles one wishes to evaluate, navigating through the literature cited, and using a visual table of citations organized chronologically by article. Currently there are 24 accounting periodicals indexed in the Scopus database, of which only 2 are not available at the CAPES portal (Accounting and Business Research and Accounting, Business and Financial History). Chart 2 illustrates the periodicals indexed in the database, and also the ISI indexing (2005), and the respective impact levels according to JCR (2004). 
Chart 2. Indexing and Impact Factor of the Periodicals

\begin{tabular}{l|c|c|c}
\hline Periodical & SCOPUS & ISI & JCR \\
\hline Abacus & Yes & Yes & - \\
\hline Accounting Forum & Yes & No & - \\
\hline Accounting Review & Yes & Yes & 1.420 \\
\hline Accounting, Auditing and Accountability Journal & Yes & No & - \\
\hline Accounting, Organizations and Society & Yes & Yes & 1.098 \\
\hline Auditing & Yes & Yes & 0.279 \\
\hline British Accounting Review & Yes & No & - \\
\hline Canadian Accounting Perspectives & Yes & No & - \\
\hline Contemporary Accounting Research & Yes & Yes & 0.660 \\
\hline Critical Perspectives on Accounting & Yes & No & - \\
\hline International Journal of Accounting & Yes & No & - \\
\hline International Journal of Accounting Inf. Systems & Yes & No & - \\
\hline Journal of Accounting Education & Yes & No & - \\
\hline Journal of Accounting Research & Yes & Yes & 1.844 \\
\hline Journal of Accounting and Economics & Yes & Yes & 1.893 \\
\hline Journal of Accounting and Public Policy & Yes & Yes & - \\
\hline Journal of International Acc., Aud. and Taxation & Yes & No & - \\
\hline Journal of Business, Finance and Accounting & No & Yes & - \\
\hline Management Accounting Research & Yes & No & - \\
\hline Managerial Auditing Journal & Yes & No & - \\
\hline Review of Accounting Studies & Yes & Yes & - \\
\hline Review of Quantitative Finance and Accounting & Yes & No & - \\
\hline Total & $\mathbf{2 2}$ & $\mathbf{1 0}$ & $\mathbf{6}$ \\
\hline
\end{tabular}

Source: The authors.

As shown in the above chart, only 10 academic periodicals on accounting are indexed according to the Institute for Scientific Information, all of them also available at the CAPES portal. The ISI, through Journal Citation Reports, also quantitatively evaluates the main academic periodicals in different areas of knowledge. JCR uses a ranking method that measures the average number of citations of the articles published, i.e., the average number of times an article is cited by peer authors. The impact factor is the average of the number of articles published in the two previous years divided by the total number of articles published in these two years. Hence, when the articles in a certain period are frequently cited, the impact level is high.

For example, the magazine Cell, in the area of genetics and cellular biology, has an impact level of 28.389 (JCR, 2004). There are only 16 Brazilian periodicals indexed by JCR. Of these, the Journal of the Brazilian Chemical Society has the highest impact level in Latin America (1.161). In this sense, it should be mentioned that the JCR impact level is currently the most often used bibliometric index to evaluate the quality of a scientific periodical or institution. Even the researcher is evaluated by the impact index generated by his or her publications. However, although indicators can assess the scientific impact, this is not necessarily a synonym for quality. An author may be cited many times because of errors or suspect findings.

The academic periodical on accounting with the highest impact according to JCR (2004) is Journal of Accounting and Economics, with 1.893, followed by Journal of Accounting Research with 1.884 and Accounting Review with 1.420. Therefore, according to 
the criteria established by JCR, these are the three leading academic periodicals on accountancy.

To publish an article in the leading accounting periodicals is no easy task. Accounting Review, for example, has a rejection rate of around 88\% (Editorial, 2005).

No Brazilian author has an article published in the accounting periodicals indexed by the ISI. Authors from other foreign countries face the same hurdles. In a study in Canada, Mathieu and McConomy (2003) stated that professors at Canadian universities publish roughly one article every seven years. In the ten main accounting journals, this average rises to one article every ten years.

\subsection{Classification of the Periodicals}

Classification of the periodicals into sub-areas of accounting involves a problem similar to that encountered by Frezatti and Borba (2000), in the sense that in the majority of periodicals the editorial policy is very superficial. Thus, we did not classify periodicals that cover different topics in the accounting area into specific areas. Instead, we used the following eight clusters:

[1] Financial Accounting / External Users. Practices, principles and financial statements, capital market, finance, economics, econometric models, etc.

Management / Control Accounting. Internal users, management, budgeting, costs, prices, performance evaluation, management methodologies, $\mathrm{BSC}, \mathrm{ABC}, \mathrm{TQM}$, etc.

Accounting Education. Undergraduate and postgraduate curricula and programs, teaching methods, training and critical attitude of accountants, etc.

Technology. Information systems to support management, specialized systems, intelligent systems, Internet information technology, Websites, etc.

History of Accounting. Development, history and evolution of accounting, future trends, etc.

Public Accounting. Public budgets and accountancy practices, governmental accounting standards and principles, government management, etc.

Auditing. Internal and external auditing, the auditing profession, new auditing technologies and standards, ethics in auditing, etc.

Diverse Topics in Accounting. This cluster includes periodicals that cover different topics in the area of accounting. The Revista de Contabilidade de Finanças da USP, for example, fits in this cluster because it publishes articles on management and financial accounting, auditing, etc.

After this classification, we collated information on three questions: publication frequency, blind review and whether submission of articles implies payment of a fee. The results of these classifications are shown below.

\subsubsection{Financial Accounting / External User Periodicals}

Of the 49 periodicals selected, 14 deal exclusively with themes related to financial accounting. This reflects the big influence of the capital market and large corporations on the development of scientific research in accounting. Since the seminal works of Beaver (1968), Ball and Brown (1968) and Watts and Zimmerman (1978), positive accounting has represented a large part of the academic production in the United States and the world at large. The periodicals listed below are a rich source or research for academics interested in the area of positive accounting, economics and finance. 
Chart 3. Financial Accounting / External Users Periodicals

\begin{tabular}{l|c|c|c}
\hline Periodical & $\begin{array}{c}\text { Issues/ } \\
\text { year }\end{array}$ & $\begin{array}{c}\text { Blind } \\
\text { Review }\end{array}$ & $\begin{array}{c}\text { Submission } \\
\text { fee }\end{array}$ \\
\hline Accounting and Finance & 4 & Yes & Yes \\
\hline Accounting Review & 4 & Yes & Yes \\
\hline Bank Accounting and Finance & 6 & Yes & No \\
\hline Canadian Accounting Perspectives & 2 & Yes & Yes \\
\hline Contemporary Accounting Research & 4 & Yes & Yes \\
\hline Journal of Accounting and Economics & 4 & Yes & Yes \\
\hline Journal of Accounting Research & 5 & Yes & Yes \\
\hline $\begin{array}{l}\text { Journal of Accounting, Auditing and } \\
\text { Finance }\end{array}$ & 4 & Yes & Yes \\
\hline Journal of Bank Accounting and Auditing & 2 & Yes & No \\
\hline $\begin{array}{l}\text { Journal of Business Finance and } \\
\text { Accounting }\end{array}$ & 5 & Yes & Yes \\
\hline $\begin{array}{l}\text { Journal of Corporate Accounting and } \\
\text { Finance }\end{array}$ & 6 & Yes & No \\
\hline Review of Accounting and Finance & 4 & Yes & No \\
\hline Review of Accounting Studies & 3 & Yes & Yes \\
\hline $\begin{array}{l}\text { Review of Quantitative Finance and } \\
\text { Accounting }\end{array}$ & 8 & Yes & Yes \\
\hline Source: Thanthors.
\end{tabular}

Source: The authors.

Of the six periodicals ranked by JCR in 2004, four focus on financial accounting (Accounting and Finance, Accounting Review, Contemporary Accounting Research and Journal of Accounting and Economics), demonstrating that financial accounting is the subarea of accounting that has the highest ranking by this index. The articles published in these periodicals come from positive research with strong quantitative focus. The development of sophisticated econometric models and statistical techniques to test hypotheses is what characterizes the majority of the publications listed in this cluster.

The frequency of these financial accounting periodicals varies, with six of the fourteen selected appearing six times a year. All the periodicals listed use blind review to evaluate articles. Most of them charge a submission fee, the highest being 300 dollars for the Journal of Accounting and Economics.

\subsubsection{Management and Control Accounting Periodicals}

Seven periodicals focus mainly on management accounting. Two of these deal exclusively with themes related to costs (Cost Management and Cost Engineering). Chart 4 shows the management accounting publications available via the CAPES portal. 
Chart 4. Management / Control Periodicals.

\begin{tabular}{l|c|c|c}
\hline Periodical & $\begin{array}{c}\text { Issues/ } \\
\text { year }\end{array}$ & $\begin{array}{c}\text { Blind } \\
\text { Review }\end{array}$ & $\begin{array}{c}\text { Submission } \\
\text { fee }\end{array}$ \\
\hline Financial Accountability and Management & 4 & Yes & No \\
\hline Management Accounting Quarterly & 4 & Yes & No \\
\hline Management Accounting Research & 4 & Yes & No \\
\hline Cost Management & 6 & Yes & No \\
\hline Cost Engineering & 12 & No & No \\
\hline Journal of Management Accounting Research & 1 & Yes & Yes \\
\hline $\begin{array}{l}\text { Journal of International Financial Mgmt. and } \\
\text { Accounting }\end{array}$ & 3 & Yes & Yes \\
\hline
\end{tabular}

Source: The authors.

Among the management accounting periodicals listed in Chart 4, special mention should go to Management Accounting Research, published by the Chartered Institute of Management Accountants in the United Kingdom. Its editorial board, headed by Robert W. Scapens, has academics from 17 countries, which shows its international scope.

Other academic reviews, such as Accounting, Organization and Society, headed by Antony Hopwood, also have very diversified editorial boards. This journal focuses mainly on the relationship between accounting and human behavior, organizational structures and social change processes, the political climate of organizations, behavioral aspects of budgeting, planning and executive compensation. Critical Perspectives on Accounting also deals with themes related to management accounting and aspects of the political environment. However, since Critical Perspectives on Accounting and Accounting, Organization and Society also publish articles on other areas of accounting (education, accounting history, etc.), we chose not to classify them in this cluster.

\subsubsection{Accounting Education Periodicals}

The CAPES portal offers two academic publications in English that deal specifically with accounting education, one published by the American Accounting Association (Issues in Accounting Education) and the other by the International Association of Accounting Education and Research (Journal of Accounting Education).

Chart 5. Accounting Education Periodicals

\begin{tabular}{l|c|c|c}
\hline Periodical & $\begin{array}{c}\text { Issues/ } \\
\text { year }\end{array}$ & $\begin{array}{c}\text { Blind } \\
\text { Review }\end{array}$ & Submission fee \\
\hline Issues in Accounting Education & 4 & Yes & Yes \\
\hline Journal of Accounting Education & 4 & Yes & No \\
\hline
\end{tabular}

Source: The authors.

A wide range of themes in the area of education are addressed by these publications. Case studies involving contemporary themes such as accounting fraud, analysis of the curricula of undergraduate and postgraduate programs in accountancy, review of periodicals, analysis of faculty productivity and new teaching technologies are some examples. These articles generally take a qualitative approach, and their editorial boards are concerned with improving the accounting profession. 


\subsubsection{Accounting Technology Periodicals}

Just as in other areas of scientific knowledge, technology affects accounting. The CAPES portal provides access to five English language periodicals that deal with themes related to technology in the accounting area. These publications are shown in Chart 6.

Chart 6. Accounting Technology Periodicals.

\begin{tabular}{l|c|c|c}
\hline Periodical & $\begin{array}{c}\text { Issues/ } \\
\text { year }\end{array}$ & $\begin{array}{c}\text { Blind } \\
\text { Review }\end{array}$ & $\begin{array}{c}\text { Submission } \\
\text { fee }\end{array}$ \\
\hline Accounting Technology & 12 & No & No \\
\hline $\begin{array}{l}\text { Accounting, Management and Information } \\
\text { Technologies }\end{array}$ & 4 & Yes & No \\
\hline $\begin{array}{l}\text { International Journal of Accounting Information } \\
\text { Systems }\end{array}$ & 4 & Yes & No \\
\hline $\begin{array}{l}\text { International Journal of Digital Accounting Research } \\
\begin{array}{l}\text { International Journal of Intelligent Sys. in Acc., Fin. } \\
\text { and Mgt. }\end{array}\end{array}$ & 2 & Yes & No \\
\hline
\end{tabular}

Source: The authors.

All the periodicals listed above, with the exception of Accounting Technology, use blind peer review to evaluate their articles. International Journal of Digital Accounting Research, published by Universidad de Huelva, despite its Spanish origin, only publishes articles in English. This is indicative of the trend to use English as the lingua franca of science, and the fact that Brazilian researchers wanting to have their ideas widely read and recognized internationally need to publish them in English.

\subsubsection{Accounting History Periodicals}

The historical emergence and development of accounting is covered by two periodicals in English available via the CAPES portal.

Chart 7. Accounting History Periodicals

\begin{tabular}{l|c|c|c}
\hline Periodical & $\begin{array}{c}\text { Issues/ } \\
\text { year }\end{array}$ & $\begin{array}{c}\text { Blind } \\
\text { Review }\end{array}$ & $\begin{array}{c}\text { Submission } \\
\text { fee }\end{array}$ \\
\hline Accounting Historians Journal & 2 & Yes & No \\
\hline Accounting History & 4 & Yes & No \\
\hline
\end{tabular}

Source: The authors.

Published by the Accounting and Finance Association of Australia and New Zealand (AFAANZ), Accounting History is the newest acquisition of the CAPES portal in the accounting area. Distributed by Sage, this periodical only became available at the end of 2005.

\subsubsection{Public Accounting Periodicals}

Public accounting in the United States is regulated by a specific entity, the Government Accounting Standards Board (GASB, www.gasb.org), and its principles and standards differ from those of private accounting, which is regulated by the Financial Accounting Standards Board (FASB, www.fasb.org). Aspects of public accounting are covered by the three publications listed below. 
Chart 8. Public Accounting Periodicals

\begin{tabular}{l|c|c|c}
\hline Periodical & $\begin{array}{c}\text { Issues/ } \\
\text { year }\end{array}$ & $\begin{array}{c}\text { Blind } \\
\text { Review }\end{array}$ & $\begin{array}{c}\text { Submission } \\
\text { fee }\end{array}$ \\
\hline Journal of Accounting and Public Policy & 6 & Yes & No \\
\hline Journal of Public Budgeting, Acc. and Fin. Mgt. & 4 & Yes & No \\
\hline International Journal of Government Auditing & 4 & No & No \\
\hline
\end{tabular}

Source: The authors.

\subsubsection{Auditing Periodicals}

The CAPES portal makes available three English language publications devoted specifically to auditing.

Chart 9. Auditing Periodicals

\begin{tabular}{l|c|c|c}
\hline Periodical & $\begin{array}{c}\text { Issues/ } \\
\text { year }\end{array}$ & $\begin{array}{c}\text { Blind } \\
\text { Review }\end{array}$ & $\begin{array}{c}\text { Submission } \\
\text { fee }\end{array}$ \\
\hline Auditing & 2 & Yes & Yes \\
\hline Internal Auditing & 6 & Yes & No \\
\hline Managerial Auditing Journal & 8 & Yes & No \\
\hline
\end{tabular}

Source: The authors.

Auditing, published by the American Accounting Association, is the only auditing periodical that is indexed in the Scopus and ISI databases. It is also the only one that has an impact level, which is 0.279 (JCR, 2004), and thus can be considered the most important periodical in the area of auditing.

\subsubsection{Periodicals on Diverse Topics in Accounting}

This cluster contains the academic publications that deal with various themes in accountancy, in other words, more general periodicals. Nevertheless, this does not mean that these publications are not academic or relevant. On the contrary, some of the main accounting titles in English are contained in this cluster, such as Accounting, Organization and Society, Critical Perspectives in Accounting, Abacus and International Journal of Accounting. 
Chart 10. Periodicals on Diverse Accounting Topics

\begin{tabular}{l|c|c|c}
\hline Periodical & $\begin{array}{c}\text { Issues/ } \\
\text { year }\end{array}$ & $\begin{array}{c}\text { Blind } \\
\text { Review }\end{array}$ & $\begin{array}{c}\text { Submission } \\
\text { fee }\end{array}$ \\
\hline Abacus & 4 & Yes & Yes \\
\hline Accounting Forum & 4 & Yes & No \\
\hline Accounting Horizons & 4 & Yes & Yes \\
\hline Accounting, Auditing and Accountability Journal & 6 & Yes & No \\
\hline Accounting, Organizations and Society. & 8 & Yes & No \\
\hline Behavioral Research in Accounting & 1 & Yes & Yes \\
\hline British Accounting Review & 4 & Yes & No \\
\hline Construction Accounting and Taxation & 6 & No & No \\
\hline Critical Perspectives on Accounting & 8 & Yes & No \\
\hline International Journal of Accounting & 4 & Yes & No \\
\hline Journal of Accounting Literature & 1 & Yes & Yes \\
\hline Journal of International Accounting Research & 1 & Yes & No \\
\hline Journal of International Accounting, Auditing and & & & No \\
Taxation & 2 & Yes & \\
\hline \multicolumn{2}{|l|}{ Source: The author. }
\end{tabular}

Source: The authors.

As their classification implies, these periodicals examine a wide array of accounting themes. The articles published in Behavioral Research in Accounting and Critical Perspectives in Accounting mainly use a qualitative approach and are extremely critical. Journal of Accounting Literature publishes various articles that review sets of studies, trying to verify the state of the art in a determined field of accounting. Construction Accounting and Taxation, as the title indicates, deals mainly with themes related to taxes, financial and general accounting in the construction sector.

\section{CONCLUSIONS}

The objective of this study was to learn some of the characteristics of the academic periodicals in the field of accounting published in English and available at the CAPES Periodicals Portal. The sample analyzed consisted of 49 publications and used as a methodology the analysis of the periodicals' editorial board, guide for authors and aim/focus. Our conclusions can be summarized as follows:

The CAPES portal provides access to academic publications in virtually all areas of accounting, thus representing a rich source of information for Brazilian researchers. The financial accounting cluster contained the most publications (14).

All the periodicals were indexed by the Institute for Scientific Information (ISI) as of 2005. According to the impact level measured by Journal Citation Reports (2004), the leading academic publications in accounting are: Journal of Accounting and Economics (1.893), Journal of Accounting Research (1.884), Accounting Review (1.420), Accounting, Organization and Society (1.098), Contemporary Accounting Research (0.660) and Auditing (0.279).

(1) The main periodicals use blind peer review to judge their articles. Some of them charge a submission fee, which varies from 50 to 300 dollars. It is very hard to publish articles in these publications, and no Brazilian author has articles in the journals indexed by the ISI. In this sense, although the accounting area has a huge range of topics and areas of investigation, the approval of articles in the top journals is considered very difficult by the majority of academics. 
This study is merely preliminary and exploratory. Its main contribution is to identify and classify the academic publications on accounting in English available at the CAPES portal. In this sense, this study seeks to contribute to the progress of accounting research in Brazil, whetting the interest of researchers and alerting them to the need to internationalize their research. With the recent creation of the Association of Postgraduate Programs in Accounting Sciences (ANPCONT) and the growing number of masters and doctorate degrees in accounting awarded in Brazil, it is extremely important to encourage Brazilian authors to seek international insertion in the field of accountancy. We once again recall the famous dictum: Publish or Perish!

\section{REFERENCES}

ADHIKARI, A; TONDKAR, R; HORA, J. An analysis of international accounting research in Journal of International Accounting Auditing \& Taxation: 1992 - 2001. Journal of International Accounting Auditing \& Taxation. V.11, pp.39-49, 2002.

BALL, R.; BROWN, J. An empirical evaluation of accounting income numbers. Journal of Accounting Research. V.6, pp.159-178, 1968.

BARDIN, L. Análise de Conteúdo. Lisboa Edições, 1977.

BEATIE, V.; GOODACRE, A. Publishing patterns within the UK accounting and finance academic community. The British Accounting Review. Article in the press, pp. 1-38, 2003.

BEAVER, W. The information content of earnings announcements. Journal of Accounting Research. V.6, Empirical Research in Accounting: Selected Studies 1968 pp. 67-92, 1968.

BORKOWSKI, S; WELSH, M. Ethical practice in the accounting publishing process: contrasting opinions of authors and editors. Journal of Business Ethics. N.25, pp.15-31, 2000. CARDOSO, R; PEREIRA, C; GUERREIRO, R. A Produção Acadêmica em Custos no Âmbito do Enanpad: Uma Analise de 1998 a 2003. Enanpad, 2004.

CHANG, K; CHENG, C; CHENG, L. Ranking research productivity in accounting for AsianPacific Universities. Review of Quantitative Finance and Accounting. V. 24, p.47-64, 2005.

EDITORIAL. Accounting Review, P.1261, Oct. 2005.

FINANCIAL ACCOUNTING STANDARD BOARD - FASB. www.fasb.org

FRANCO, M. Análise de Conteúdo. Editora Plano, Brasília, 2003.

FREZATTI, F; BORBA, J. Análise dos traços de tendência de uma amostra das revistas cientificas da área de contabilidade publicadas em língua inglesa. Caderno de Estudos Fipecafi. Vol. 13, n.25, pp.50-78, 2000.

GOVERNMENT ACCOUNTING STANDARDS BOARD (GASB). www.gasb.org

HORNSTEIN, D. Accounting for science: the independence of public research in the new, subterranean administrative law. Public Law \& Legal Theory. pp.1-32, 2003.

HOWARD, T; NIKOLAY, L. Attitude measurement and perceptions of accounting faculty publications outlets. The Accounting Review. V.58, n.4, pp.765-776, 1983.

HUBBARD, R; VETTER, D. An empirical comparison of published replication research in accounting, economics, finance, management, and marketing. Journal of Business Research. V.35, pp. 153-164, 1996.

HULL, R; WRIGHT, G. Faculty perceptions of journal quality: an update. Accounting Horizons. V.4, n.1, pp. 77-98, 1990

INSTITUTE FOR SCIENTIFIC INFORMATION - ISI. www.isinet.com. JOURNAL CITATION REPORTS - JCR. www.isinet.com 
LEITE FILHO, G; MARTINS, G. Relação orientador -orientando e suas influencias no processo de elaboração de teses e disssertações dos programas de pós- graduação em contabilidade da cidade de São Paulo. Enanpad 2005.

LUKKA, K; KASANEN, E. Is accounting a global or a local discipline? Evidence from major research journals. Accounting, Organization and Society. V.21, n.7, pp.755-773, 1996. MARION, J. Aspectos do ensino da contabilidade nos Estados Unidos. Caderno de Estudos Fipecafi. n.7, pp.1-66, 1992.

MARTINS, G. Considerações sobre os doze anos do caderno de estudos, divulgação de trabalho. Revista Contabilidade \&Finanças -USP, São Paulo, n.30,pp. 81-88

MATHIEU, Robert. McCONONY, Bruce. Productivity in "Top-Ten" Academic Accounting Journals by Researchers at Canadian Universities. Canadian Accounting Perspectives. Vol. 2, n 1., pp. 43-76, 2003.

MENDONÇA NETO, O et al. Estudo sobre as sobre as publicações cientificas em contabilidade: uma análise de 1990 até 2003. Enampad, 2004.

OLIVEIRA, M. Análise dos periódicos brasileiros de contabilidade. Revista de Contabilidade \& Finanças - USP. N.29, pp. 68-86, 2002.

PRATHER-KINSEY, J; RUESCHHOFF, N. An analysis of the authorship of international accounting research in U.S. journals and AOS: 1980 through 1996. The Internantional Journal of Accounting. V.34, n. 2, pp. 261- 282, 1999.

PORTAL CAPES. http://www.periodicos.capes.gov.br/portugues/index.jsp.

RICCIO, E.; CARASTAN, J.; SAKATA, M. Accounting research at Brazilian universities.

Asian Pacific Conference. Melbourne, Australia, 1999.

RICCIO, E.SAKATA, M. Evidencias da globalização na educação contábil: estudo das grades curriculares dos cursos de graduação em universidades Brasileiras e Portuguesas. Revista de Contabilidade \& Finanças - USP. N.35, pp. 35-44, 2004.

SCOPUS. www.info.scopus.com

SOARES, G. O portal de periódicos da Capes: dados e pensamento. Revista Brasileira de Pós- Graduação.N.1, pp.10-25, 2004.

SOLOMON, I; TROTMAN, K. Experimental judgment and decision research in auditing: the first 25 years of AOS. The Accounting Organization and Society. V. 28, pp. 395-412, 2003.

TAHAI, A; RIGBSY, J. Information processing using citation to investigate journal influence in accounting. Information Processing \& Management. V. 34, n.2, pp.341-0359, 1998.

THEOPHILO, C; IUDÍCIBUS, S. Uma análise crítico-espitemológica da produção científica em contabilidade no Brasil. Enanpad, 2005.

ZEFF, S. A study of academic research journals in accounting. Accounting Horizons. V.10, n.3, pp.158-177, 1996.

WATTS, R.; ZIMMERMAN, J. Positive Accounting. Prentice Hall, Englewood Cliffs 1986. 